\title{
招請講演
}

\section{4. 糖尿病性腎症の病態に立脚した治療}

\author{
槇野 博史
}

Key words : 糖尿病性腎症, 糸球体過剩滤過, 細胞周期, 血管新生, 炎症

\section{はじめに}

正常耐糖能, 耐糖能異常, 2 型糖尿病へと進展 する過程で, 膵Langerhans島（ラ氏島）の肥大 と細胞増殖と高インスリン血症が初期にもたら され，その後ラ氏島炎症やアポトーシスによっ て細胞の減少が進行し最終的にはラ氏島の線維 化によってインスリン分泌能の廃絶がもたらさ れる。 その過程はまさしく糖尿病性腎症の進展 過程に類似性がある。腎症の初期においては糸 球体過剩濾過や糸球体肥大がもたらされ，その 後炎症とアポトーシスによって細胞数は減少し, 最終的には糸球体硬化と間質の線維化によって 末期腎不全に至る（図 1)。腎症の研究において これらのステージにおける病態を検討し, さら に臨床研究を行ってきた。 その結果糸球体過剩 濾過と血管新生, 細胞肥大と細胞周期, microinflammationの関与を明らかにした（図 2)。さら にこれらの複数の病態に対して治療介入を行う にはチーム医療を基盤にした集約的治療が重要
であると考え臨床研究を推進している．本講演 ではこれら当科のデータを中心に概説した.

\section{1. 糸球体の過剰濾過と血管新生}

糖尿病性腎症の進行には糸球体過剩濾過が関 与しており, その成因として輸入細動脈の拡張 が指摘されている. 我々は糸球体肥大を血行動 態と血管新生の側面から検討してきた。糸球体 過剩滤過は糖尿病性腎症の最も早期の変化であ るが, 輸入細動脈と糸球体毛細血管の拡張には, 輸入細動脈内皮細胞や糸球体内皮細胞の, ecNOS (endotherial cell nitric oxide synthase)の発現が 上昇して, nitric oxideの産生を増加させること によって血管拡張が引き起こされていることを 報告した ${ }^{1)}$.さらにadrenomedullinとその受容体 の輸入細動脈における発現上昇が血管拡張と糸 球体過剩濾過に関与していることを報告した2).

血管内皮増殖因子（vascular endothelial growth factor：VEGF) は代表的な血管新生促進 因子である.VEGFは腎糸球体足細胞より主とし

岡山大学大学院医歯薬学総合研究科腎 ·免疫 - 内分泌代謝内科学

109th Scientific Meeting of the Japanese Society of Internal Medicine : Invited lecture : 4. Development of new therapeutics based on the progression mechanisms of diabetic nephropathy.

Hirofumi Makino : Department of Medicine and Clinical Science, Okayama University Graduate School of Medicine, Dentistry and Pharmaceutical Sciences, Japan.

本講演は, 平成 24 年 4 月 15 日（日）京都市・みやこめっせにて行われた. 

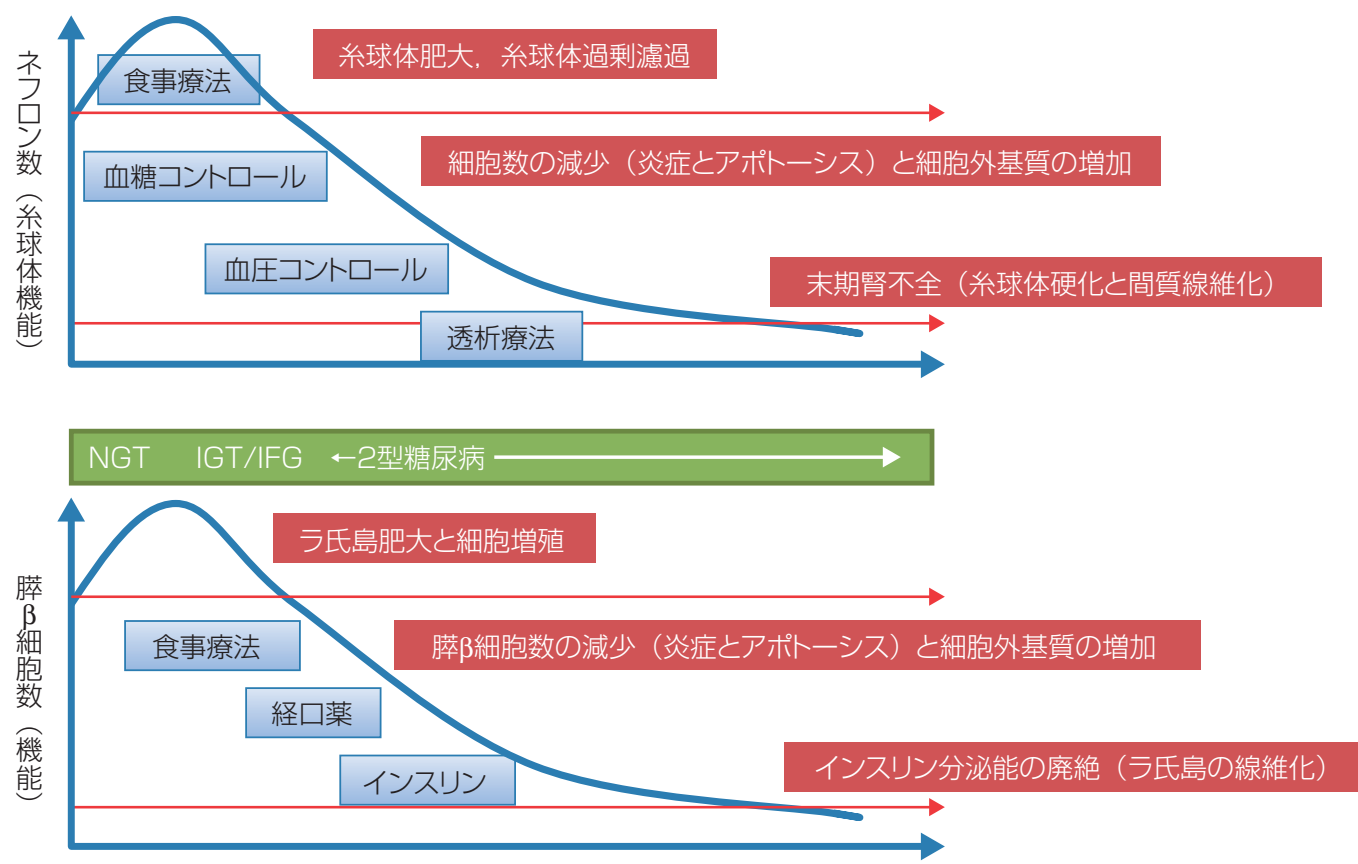

図 1. 2 型糖尿病と糖尿病性腎症進展の類似性

NGT : normal glucose tolerance

IGT : impaired glucose tolerance

IFG : impaired fasting glucose

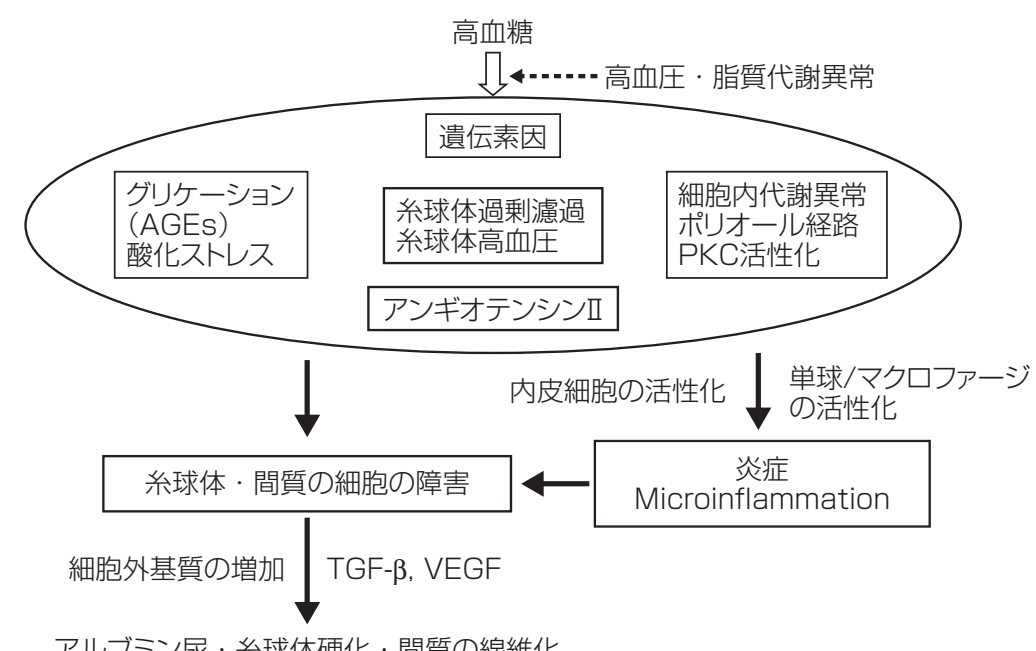

アルブミン尿・糸球体硬化・間質の線維化

図 2. 糖尿病性腎症の成因と治療標的

て産生され, 内皮細胞上の受容体VEGFR-1 (vascular endothelial growth factor receptor-1), VEGFR-2 に作用する. 糖尿病性腎症モデルにお
ける抗VEGF療法による糖尿病性腎症の治療効果 が示されているが, 直接的VEGF阻害薬以外にも, 種々の血管新生抑制因子による腎症治療効果を 

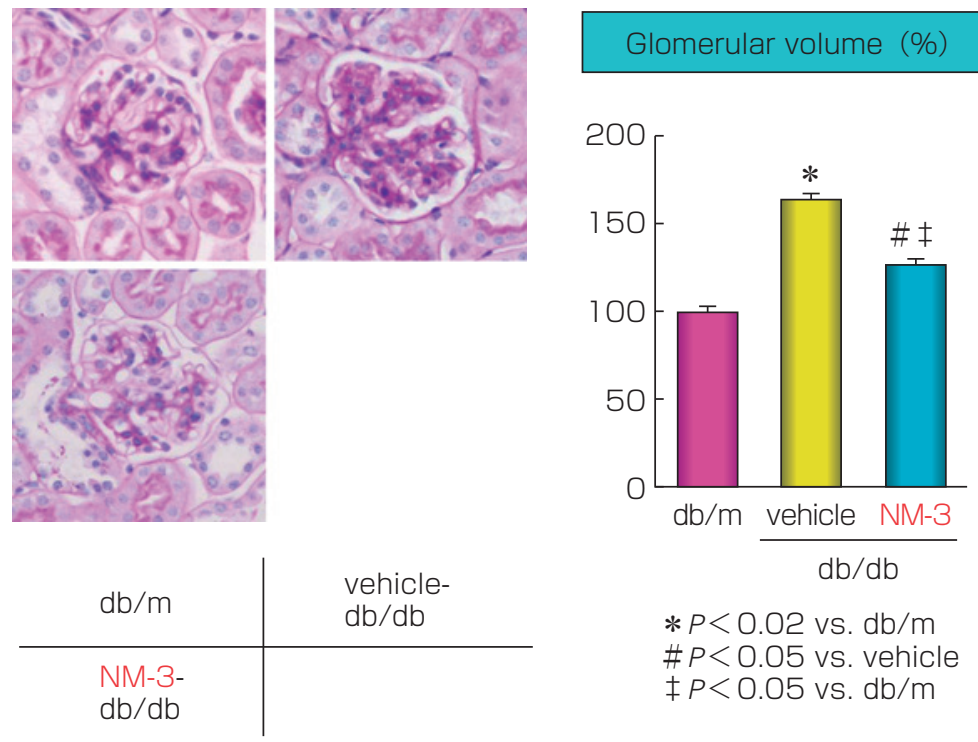

$\mathrm{db} / \mathrm{db}$

$* P<0.02$ vs. $\mathrm{db} / \mathrm{m}$ $\# P<0.05$ vs. vehicle $\ddagger P<0.05$ vs. $\mathrm{db} / \mathrm{m}$

図 3. 血管新生抑制因子による糖尿病性腎症治療効果

報告してきた。当科の前島らは血管新生抑制因 子であるtumstatin ${ }^{3)}$, endostatin ${ }^{4)}, \mathrm{NM}-3^{5)}$ の投 与によって, 糸球体肥大とアルブミン尿が抑制 され，血管新生が糖尿病性腎症の発症初期のメ カニズムとして重要であることを明らかにした (図 3). 血管内皮細胞をVEGF刺激した際に発現 増加する遺伝子の中から血管新生抑制作用を示 すvasohibin-1 (VASH-1) が東北大学の佐藤らに よって新たに同定されたが, VASH-1 はsprouting (発芽) 等の活発な血管新生部位では発現が 低下し，血管新生終息部位にて発現増加し，血 管新生の終息/血管の成熟に関与すると考えられ る. 当科の前島らは, VASH-1 発現アデノウィル スベクター（AdVASH-1）をSTZ（streptozotocin）誘発 1 型糖尿病モデルマウス並びに 2 型糖 尿病モデルである $\mathrm{db} / \mathrm{db}$ マウスに静脈内投与し, 腎症変化の有意な抑制効果を観察した ${ }^{6,7)}$. STZ 群における腎皮質でのTGF- $\beta$ （transforming grow th factor- $\beta$ ), macrophage chemoattractant1 (MCP-1), receptor for AGE (advanced glycation endoproduct) (RAGE), VEGFR-2 発現増加 ならびにリン酸化がAd-hVASH-1 投与群で有意
に抑制された. 内在性血管新生制御因子VASH1 を外因性に投与することにより, 内皮細胞のみ ならずメサンギウム細胞への直接作用をも介し て血管新生制御・抗線維化・抗炎症・AGE作用 抑制等の機序から糖尿病性腎症の進展を制御す る可能性が示唆された.

\section{2. 糖尿病性腎症と細胞周期異常}

糖尿病性腎症に認められる細胞肥大は, 蛋白 合成の充進と G1 期細胞周期停止が関与しており, サイクリンインヒビターである $\mathrm{p} 21^{\mathrm{Cip} 1}, \mathrm{p} 27^{\mathrm{Kip} 1}$ の活性化が関与していると指摘されてきている. 我々はpioglitazoneをOLETF (Otsuka LongEvans Tokushima Fatty)ラットに投与したとこ ろ, 糸球体上皮細胞において増加したp $21^{\mathrm{Cip} 1}$, $\mathrm{p} 27^{\mathrm{Kip} 1}$ 陽性細胞を減少させ, IV型コラーゲンや TGF- $\beta$ の発現が減少して, 細胞外基質の蓄積やマ クロファージの浸潤，そしてアルブミン尿や系 球体肥大が抑制されることを報告した. peroxisome proliferator activated receptor (PPAR $\gamma$ ) はメサンギウム細胞さらには糸球体上皮細胞に 
発現しており，これらの細胞が作用ターゲット となっていると考えられる8). さらにgalectin-9 は, 活性化T細胞や胸腺細胞などの細胞にアポ トーシスを誘導することが知られており細胞周 期制御の調節因子である. そこで $\mathrm{db} / \mathrm{db}$ マウスに galectin-9 リコンビナント蛋白を投与したところ, galectin-9 が糖尿病性腎症のG1 期における細胞周 期停止を正常化して, 腎症への治療効果を発揮 することを報告した ${ }^{9}$.

\section{3. microinflammationの関与}

典型的な炎症性疾患の病態は, 発赤・腫脹・ 疼痛・変形・機能障害を主徵とするものであり, 血清学的にはCRP (C-reactive protein) の上昇 や赤沈の元進を伴い, 関節リウマチや血管炎な どが代表的な炎症性疾患である.これに対して， 動脈硬化や糖尿病性腎症に見られる「炎症」は, 従来の炎症の概念とは異なり，血管壁を主座と する軽度の慢性炎症であり, CRPの上昇も高感 度測定キットで検出されるレベルであることか ら (高感度CRP), 我々は両者を区別するために microinflammationと呼んでいる. microinflammationの基本的病態の一つは内皮細胞障害（内 皮細胞の活性化）であり，他の炎症性疾患と同 様に血管壁に細胞接着分子, ケモカインの発現 克進とマクロファージの浸潤を認める.

糖尿病性腎症の成因に炎症が関与するという 仮説を提示して,一連の研究でこれを検証した. 1993 年に古田らによって糖尿病性腎症の腎組織 に炎症細胞が浸潤することが報告されたが，当 科の四方らは糖尿病性腎症患者と糖尿病動物の 腎組織にマクロファージの浸潤と ICAM-1 (intercellular adhesion molecule-1) などの接着分子の 発現立進が起こることを明らかにし，糖尿病性 腎症の発症進展に炎症が関与している可能性を 示した ${ }^{10)}$.さらに我々は, ICAM-1ノックアウト マウス ${ }^{11)}$, macrophage scavenger receptor-A ノックアウトマウス ${ }^{12)}$ では, ストレプトゾトシン
誘導糖尿病において糸球体内へのマクロファー ジの浸潤が抑制されることによって，アルブミ ン尿や糸球体の細胞外基質の増加が抑制される ことを示し，これらの接着分子を阻害すること が，炎症の抑制と腎症の治療に有用であること を示した（図 4). hydroxymethylglutaryl-CoA reductase還元酵素阻害薬 (以下スタチンと略す) はコレステロール低下作用のみならず，多面的 作用により動脈硬化領域で欠かすことのできな い薬剤である. スタチンの多面的作用の一つは 抗炎症作用である. メバロン酸経路の下流の低 分子 $\mathrm{G}$ 蛋白, nuclear factor-kappa B (以下NF-кB と略す）などの転写因子の発現が抑制され, 酸 化ストレスの低下が惹起されることが知られて いる. スタチンの抗炎症作用が腎症の発症進展 を抑制するという仮説を立て, 糖尿病ラットに スタチンを投与したところ, 血糖やコレステロー ル值の変化なくアルブミン尿が低下した（げっ 歯類では酵素の誘導が起こるためスタチンによ る長期的なコレステロール低下作用は認められ ない). 当科の片岡らはスタチン投与群が腎臓に おけるICAM-1 の発現低下, マクロファージの浸 潤抑制, DNA (deoxyribonucleic acid)の酸化マー カーである 8-hydroxydeoxyguanosine（以下 8OHdGと略す)の発現を抑制し, NF-kBの活性化 を抑制することを報告した ${ }^{13)}$. その後当科におい て炎症を制御する可能性を持つ薬剂を用いて動 物モデルで検討したところ, チアゾリジン系薬 14), 免疫抑制薬15)などでも同様のメカニズムで腎 症の発症進展を抑制することが示された.

また最近糖尿病の治療において重要な位置を 占めている glucagon-like peptide-1 (GLP-1) 受容 体アゴニストは, 当科の小寺らの検討により腎 症においても血糖に影響されない腎症抑制効果 を有し, そのメカニズムの一つとしてマクロ ファージの腎組織への浸潤抑制, NF- $\mathrm{NB}$ の発現抑 制, 酸化ストレスの抑制などを含む炎症の抑制 が示された ${ }^{16)}$. GLP-1 受容体は膵蔵のみならずマ クロファージ，腎内皮細胞にも発現しており， 

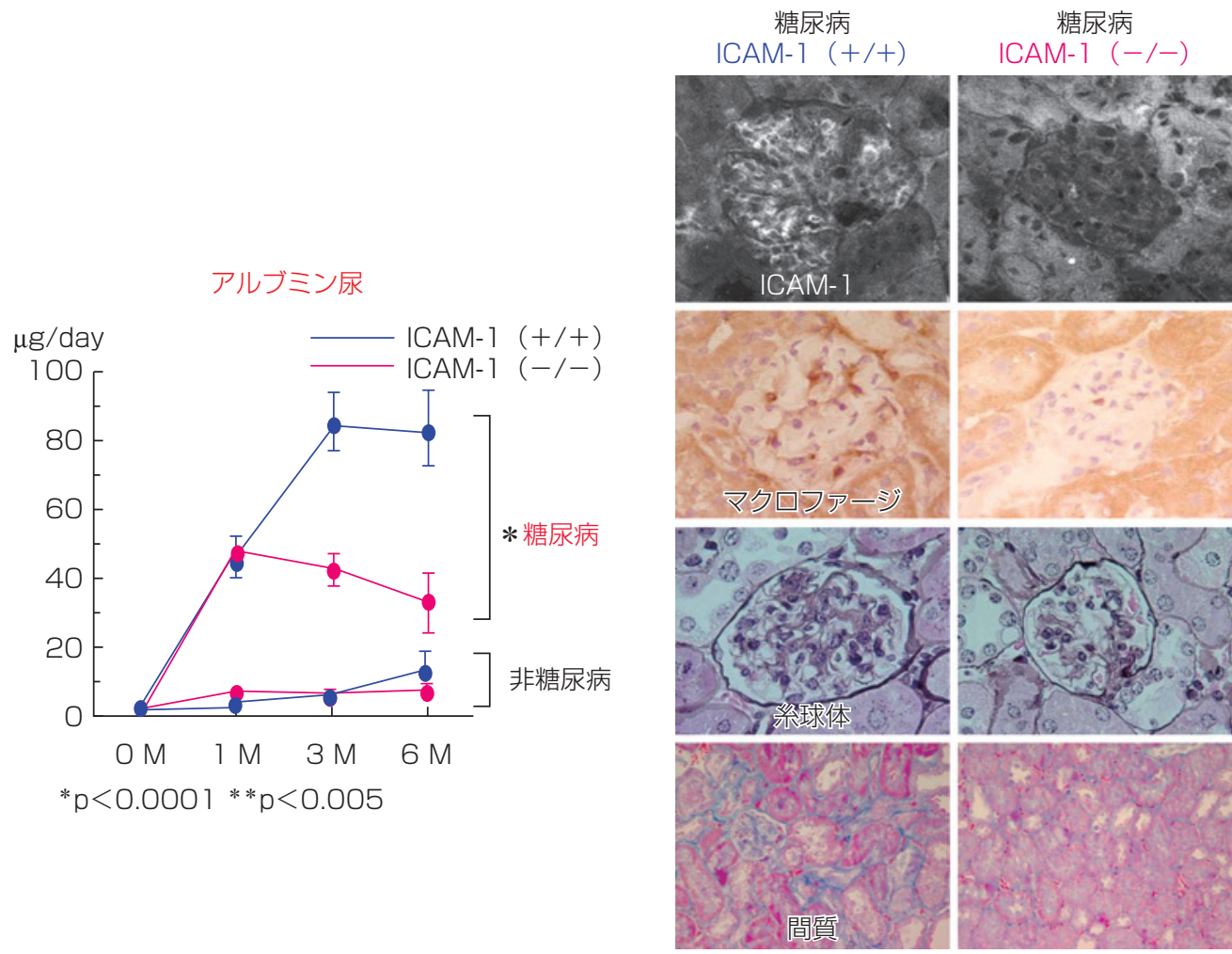

図 4. ストレプトゾトシン誘発糖尿病ICAM-1 ノックアウトマウスにおける糖尿病性腎症進展抑制 効果

抗炎症作用にはマクロファージや内皮細胞への 直接作用も関与していると考えられる。インク レチン製剤の血糖降下薬としての有用性に留ま らない多面的効果についての更なる可能性と知 見の集積が示唆される。ささに，当科ではイン スリン抵抗性や肥満の改善に効果を期待される peroxisome proliferator-activated receptor- $\delta$ (PPAR $\delta)$ アゴニストに抗炎症作用を介した腎症 抑制作用が認められると報告し ${ }^{17)}$, 今後抗炎症作 用を軸とした新たな腎症治療薬についても研究 が進んでいくことを期待するものである.

炎症の制御は，血糖・血圧コントロール，レ ニンーアンジオテンシン系の制御とともに腎症の 発症進展抑制の一角を担う治療法となる可能性 がある. 特にDPP-4 (dipeptidyl peptidase-4) 阻 害薬やGLP-1 受容体アゴニスト, PPARファミ リーのアゴニストなどの新規薬剤については,
血糖コントロールを越えた血管合併症の制御の 可能性も有しており，今後更なる知見の集積が 待たれる。

\section{4. 糖尿病性腎症のバイオマーカー}

早期糖尿病性腎症の gold standardは微量アル ブミン尿である。しかし，アルブミン尿は高血 圧 (良性腎硬化症)，高度肥満，メタボリック・ シンドロームでも陽性になるので注意が必要で ある.IV型コラーゲン定量が糖尿病性腎症の早 期診断の指標としての意義を初めて報告した ${ }^{18)}$. IV 型コラーゲンは生体の細胞外マトリックスの 構成成分であり，腎では主として糸球体基底膜 に分布している，糖尿病性腎症では，糸球体の 基底膜肥厚とメサンギウム領域の拡大が特徵的 な変化であり,これはIV型コラーゲンを主体と 
する細胞外マトリックスの増加に起因する。こ のため尿中アルブミンなどの血中由来蛋白が, 糸球体の透過性異常を反映するのに対し, 尿中 IV 型コラーゲンは, 糸球体組織由来であるため 糸球体の傷害自体を反映する指標と考えること ができる.糖尿病性腎症において尿中IV型コラー ゲンは, 尿中アルブミン值が正常域を示す腎症 前期（第一期）においても上昇し, 本法は早期 の診断並びに病態の進展予知に有用である。 ま た, 血清中の高感度CRPや種々の炎症関連サイ トカインは糖尿病患者で上昇することが報告さ れてきた. 活性化マクロファージから分泌され るinterleukin-18（IL-18）は冠動脈疾患患者の予 後予測因子として有用であることが知られてい るが, 当科の中村らは糖尿病患者の血清中IL-18 が頸動脈の内膜中膜複合体, 脈波伝播速度とと もに尿中アルブミン排泄量と相関することを報 告した ${ }^{19)}$. 同様に, 当科の梶谷らはtumor necrosis factor（TNF- $\alpha)$ が尿中アルブミン排泄量や 動脈硬化マーカーと相関することを示した ${ }^{20)}$. こ れらは他の炎症関連サイトカインやICAM-1 発現 を促進させることが知られており, 動脈硬化と 腎症に共通する炎症メカニズムの一端を担う重 要な因子と考えられる。 また我々は 2 型糖尿病 患者において尿中のprostaglandin D synthase （PGDS）排泄量が，心血管イベントの発生と関 連があり，新たな心血管リスクマーカーとして 報告した ${ }^{21)}$.

\section{5. 糖尿病性腎症の治療とエビデンスの 発信}

わが国から発信されたエビデンスとして最も 重要なものは, アンジオテンシン変換酵素阻害 薬の効果を世界に先駆けて報告した田熊らの研 究である. 田熊らの報告がその後のACE阻害薬 やARB (angiotensin receptor blocker)のエビデ ンスの構築を導く先端的な研究であると考えら れる。 また熊本スタディーでは 2 型糖尿病にお
いて, 厳格な血糖コントロールが腎症の一次予 防, 二次予防いずれにおいても効果が認められ, 2 型糖尿病においても腎症の発症・進展の抑制に 血糖管理が重要であることを実証した研究とし て高く評価されている。 このように質の高い研 究がわが国から発信されているものの, その数 は欧米と比較して極端に少ないと思われる，筆 者らは 514 人の 2 型糖尿病患者を対象とした我 が国最初の大規模臨床試験であるINNOVATION studyでは, telmisartanが, 微量アルブミン尿を 呈する日本人 2 型糖尿病患者において, プラセ ボに比し有意に顕性腎症への移行を抑制し, こ の効果は, 治療開始時の高血圧の有無に関係な く認められた ${ }^{22)}$. 近年, 強力な治療介入によりネ フローゼ症候群が寛解した複数の糖尿病性腎症 の症例が報告されている。これらの知見から， 集約的な治療を行うことにより，顕性腎症期の 症例でも寛解が可能であると期待されるが, 大 規模臨床試験によるエビデンスは存在しない.

さらに著者らは顕性蛋白尿を呈する 2 型糖尿 病に伴う糖尿病性腎症患者における olmesartan の腎症進展抑制作用を検討した(ORIENT試験). 血清クレアチニンの 2 倍化, 末期腎不全, 死亡 のいずれか最も早く出現した事象を主要評価項 目とした。 その結果, 尿蛋白を有意に減少させ たものの, 腎複合エンドポイントにおいてはACE 阻害薬投与下においては更なる併用効果を認め なかった．特にrapid GFR (glomerular filtration rate) declinerと考えられる比較的急速に腎機能 が低下した群では併用効果がなかった．一方心 血管系複合エンドポイントでは，プラセボ群と 比較して $36 \%$ 有意に抑制した ${ }^{23,24)}$.

我々は, 2005 年より厚生労働省研究事業とし て, Diabetic Nephropathy Remission and Regression Team Trial (DNETT-Japan) を開始し た25). 本研究は, 顕性腎症（3 期〜4 期）を伴う 2 型糖尿病患者を対象に, 医師と糖尿病療養指導 士（CDEJ）を中心としたコメディカルスタッフ が参加するチーム医療によって強力な治療介入 


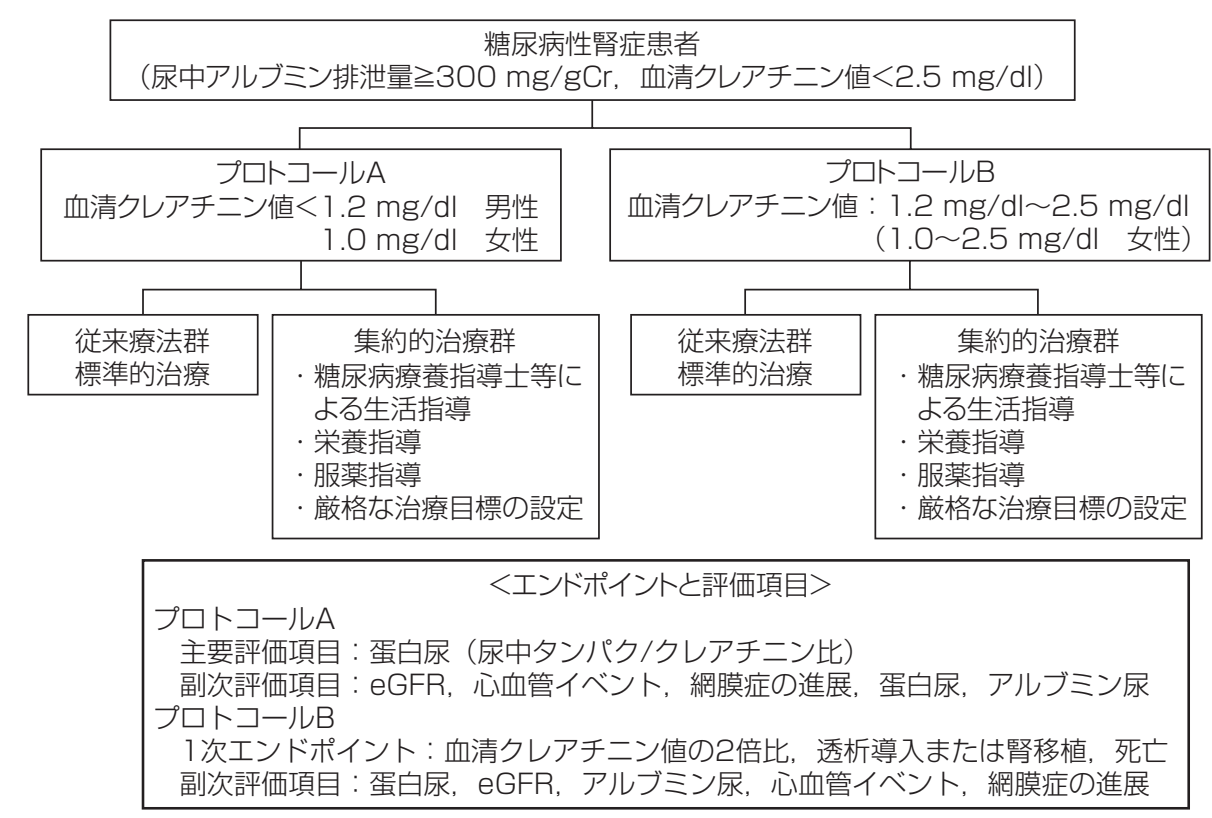

図 5. DNETT-Japanの研究プロトコール

表. DNETT-Japanの治療法と目標值

\begin{tabular}{|c|c|c|}
\hline & 従来療法群 & 集約的治療群 \\
\hline $\begin{array}{l}\text { 血糖管理 (JDS值) } \\
\text { 血圧管理 }\end{array}$ & $\begin{array}{l}\mathrm{HbA} 1 \mathrm{c}<6.5 \% \\
<130 / 80 \mathrm{mmHg}\end{array}$ & $\begin{array}{c}\mathrm{HbA} 1 \mathrm{c}<5.8 \% \\
<125 / 75 \mathrm{mmHg} \\
\text { ACE阻害薬, ARBを併用 } \\
\text { 家庭血圧測定 }\end{array}$ \\
\hline 脂質管理 & LDL.cho $<120$ mg/dl & $\begin{array}{l}\text { LDL.cho<100 mg/dl } \\
\text { スタチン系薬剤を使用 }\end{array}$ \\
\hline $\begin{array}{l}\text { 食事 : エネルギー } \\
\text { 蛋白質 } \\
\text { 食塩 }\end{array}$ & $\begin{array}{c}25 \sim 30 \mathrm{kcal} / \mathrm{kg} / 日 \\
1.0 \mathrm{~g} / \mathrm{kg} / 日 \\
6 \mathrm{~g} / 日\end{array}$ & $\begin{array}{c}30 \mathrm{kcal} / \mathrm{kg} / \text { 日 } \\
0.8 \mathrm{~g} / \mathrm{kg} / 日 \\
5 \mathrm{~g} / \text { 日 }\end{array}$ \\
\hline その他 & & 服薬指導 · 禁煙指導 · 生活指導 \\
\hline
\end{tabular}

を行う（集約的治療）ことにより, 腎症の進展 を抑制できるか否か，更には寛解させることが 可能であるかを検証する多施設共同無作為化臨 床試験である，対象は顕性腎症であり，プロト コールAでは腎機能が比較的保たれている群(第 3 期)を対象として蛋白尿の減少効果を主要評価 項目としている(図 5).プロトコールBでは血清 クレアチニン值の上昇が見られる症例 (第 4 期) を対象に血清クレアチニン值の 2 倍化, 透析療 法への導入または腎移植, 死亡を複合エンドポ
イントとして, 集約的治療法における腎症の進 行抑制効果を検討する（図 5). 両プロトコール とも, 強力な治療介入を行う集約的治療群と, 従来の治療を継続する従来療法群の 2 群に無作 為に割付けて 5 年間観察する。治療目標值は, 従来療法群では日本糖尿病学会, 日本高血圧学 会, 日本動脈硬化学会が提唱している治療ガイ ドラインに準拠しており, 集約的治療法群の場 合は,これよりも更に厳しい治療目標を設定し た(表)。薬物療法は, 従来療法群の場合は現在 
の標準的な治療を継続し, 集約的治療群では降 圧薬としてACE阻害薬とARB, 高脂血症治療薬 としてHMG-CoA還元酵素阻害薬(スタチン)を, サプリメントとしてマルチビタミンを必ず使用 する．食事療法は，デジタルカメラを用いた食 事記録などを参考に，管理栄養士が栄養指導を 行う。また, 集約的治療群では, 家庭血圧計に よる早朝血圧の測定, 禁煙指導, 服薬状況の厳 密なチェックを行い, 治療効果の向上を図る. 本研究では, 2006 年末までに全国の約 130 施設 のご参加を得て, 310 症例が観察期間に入り, 200 症例が登録されており, 現在 1 回目の中間解析 を行っているところである.上記のように, DNETT-Japanではチーム医療によって可能な限 り積極的な治療介入を行うことにより, 腎症の 進展阻止・寛解が可能か否かを検証するととも に，腎症の治療法を確立することを目指してい る.

\section{おわりに}

糖尿病性腎症の発症・進展には種々のメカニ ズムが関与していることを示してきたが，それ らの種々病態に介入するためには, チーム医療 による集約的治療が重要であると考えている. 今後も基礎研究と臨床研究を両輪として, 糖尿 病性腎症による腎不全や心血管病を抑制したい と考えている.

著者のCOI (conflicts of interest) 開示: 標野博史; 講演料 (第一三共, 日本ベーリンガーインゲルハイム), 寄付金 (第 一三共, 日本ベーリンガーインゲルハイム)

\section{文献}

1) Sugimoto $\mathrm{H}$, et al: Increased expression of endothelial cell nitric oxide synthase (ecNOS) in afferent and glomerular endothelial cells is involved in glomerular hyperfiltration of diabetic nephropathy. Diabetologia 41 : 1426-1434, 1998.

2) Hiragushi K, et al: The role of adrenomedullin and receptors in glomerular hyperfiltration in streptozotocininduced diabetic rats. Kidney Int 65 : 540-550, 2004.
3) Yamamoto Y, et al: Tumstatin peptide, an inhibitor of angiogenesis, prevents glomerular hypertrophy in the early stage of diabetic nephropathy. Diabetes 53 : 18311840, 2004.

4) Ichinose $\mathrm{K}$, et al:Antiangiogenic endostatin peptide ameliorates renal alterations in the early stage of a type 1 diabetic nephropathy model. Diabetes $54: 2891-2903$, 2005.

5) Ichinose K, et al:2-(8-hydroxy-6-methoxy-1-oxo-1h-2benzopyran-3-yl) propionic acid, an inhibitor of angiogenesis, ameliorates renal alterations in obese type 2 diabetic mice. Diabetes 55 : 1232-1242, 2006.

6) Nasu T, et al:Vasohibin-1, a negative feedback regulator of angiogenesis, ameliorates renal alterations in a mouse model of diabetic nephropathy. Diabetes $58: 2365-2375$, 2009.

7) Saito D, et al : Amelioration of renal alterations in obese type 2 diabetic mice by vasohibin-1, a negative feedback regulator of angiogenesis. Am J Physiol Renal Physiol 300 : F873-886, 2011.

8) Okada $\mathrm{T}$, et al: Thiazolidinediones ameliorate diabetic nephropathy via cell cycle-dependent mechanisms. Diabetes 55 : 1666-1677, 2006.

9) Baba M, et al : Galectin-9 inhibits glomerular hypertrophy in $\mathrm{db} / \mathrm{db}$ diabetic mice via cell-cycle-dependent mechanisms. J Am Soc Nephrol 16 : 3222-3234, 2005.

10) Sugimoto $\mathrm{H}$, et al: Increased expression of intercellular adhesion molecule-1 (ICAM-1) in diabetic rat glomeruli : glomerular hyperfiltration is a potential mechanism of ICAM-1 upregulation. Diabetes 46 : 2075-2081, 1997.

11) Okada $\mathrm{S}$, et al:Intercellular adhesion molecule-1deficient mice are resistant against renal injury after induction of diabetes. Diabetes 52 : 2586-2593, 2003.

12) Usui HK, et al:Macrophage scavenger receptor-adeficient mice are resistant against diabetic nephropathy through amelioration of microinflammation. Diabetes $56: 363-372,2007$.

13) Usui $\mathrm{H}$, et al: HMG-CoA reductase inhibitor ameliorates diabetic nephropathy by its pleiotropic effects in rats. Nephrol Dial Transplant 18: 265-272, 2003.

14) Ohga $\mathrm{S}$, et al: Thiazolidinedione ameliorates renal injury in experimental diabetic rats through anti-inflammatory effects mediated by inhibition of NF- \{kappa\} B activation. Am J Physiol Renal Physiol 2006.

15) Yozai K, et al: Methotrexate prevents renal injury in experimental diabetic rats via anti-inflammatory actions. J Am Soc Nephrol 16 : 3326-3338, 2005.

16) Kodera R, et al: Glucagon-like peptide-1 receptor agonist ameliorates renal injury through its anti-inflammatory action without lowering blood glucose level in a rat model of type 1 diabetes. Diabetologia 54 : 965-978, 2011.

17) Matsushita $Y$, et al: Activation of peroxisome proliferator-activated receptor delta inhibits streptozotocininduced diabetic nephropathy through anti-inflammatory mechanisms in mice. Diabetes 60 : 960-968, 2011. 
18) Hayashi $Y$, et al : Serum and urinary concentrations of type IV collagen and laminin as a marker of microangiopathy in diabetes. Diabet Med 9:366-370, 1992.

19) Nakamura A, et al : Serum interleukin-18 levels are associated with nephropathy and atherosclerosis in Japanese patients with type 2 diabetes. Diabetes Care $28: 2890-$ 2895, 2005.

20) Kajitani N, et al : Microinflammation is a common risk factor for progression of nephropathy and atherosclerosis in Japanese patients with type 2 diabetes. Diabetes Res Clin Pract 88: 171-176, 2010.

21) Yoshikawa R, et al : Urinary PGDS levels are associated with vascular injury in type 2 diabetes patients. Diabetes Res Clin Pract 76 : 358-367, 2007.

22) Makino $\mathrm{H}$, et al : Prevention of transition from incipient to overt nephropathy with telmisartan in patients with type 2 diabetes. Diabetes Care 30 : 1577-1578, 2007.

23) Imai $\mathrm{E}$, et al : Effects of olmesartan on renal and cardiovascular outcomes in type 2 diabetes with overt nephropathy: a multicentre, randomised, placebo-controlled study. Diabetologia 54 : 2978-2986, 2011.

24) Imai $\mathrm{E}$, et al : Olmesartan Reducing Incidence of Endstage Renal Disease in Diabetic Nephropathy Trial(ORIENT):rationale and study design. Hypertens Res 29 :703709, 2006

25) Shikata K, et al : Diabetic Nephropathy Remission and Regression Team Trial in Japan(DNETT-Japan) : rationale and study design. Diabetes Res Clin Pract 87 :228232,2010 . 